\title{
Mikä rasittaa pätkätyössä?
}

\author{
SIKKE LEINIKKI
}

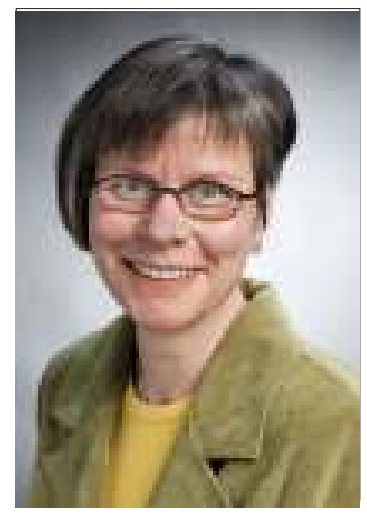

\begin{abstract}
Väitöstutkimuksessaan Sikke Leinikki tutki korkeasti koulutettujen pätkätyötä tekevien kertomuksia ja hän asemoi myös itsensä kokemuksellisesti osaksi tutkimaansa kohdetta. Leinikki tarjosi mallitarinoita, joiden avulla pätkätyöläinen voi reflektoida omaa elämäänsä. Kerronnan malleista nousi esille, miten vaikeaa pätkätyöläisen on asemoida itseään työyhteisössä ja miten paljon sosiaaliset verkostot vaikuttavat selviytymiseen. Artikkelissa Leinikki kuvaa, miten pätkätyö sitoo ja sulkee. Pätkätyö näyttäytyy pikemminkin työttömyyden kuin vakinaisen työsuhteen vaihtoehtona.
\end{abstract}

Rajaan tässä artikkelissa pätkätyön tarkoittamaan määräaikaisia työsuhteita, vaikka termi voidaan laajentaa koskemaan myös osa-aikaisia työsuhteita, itsensä mikroyrittäjänä työllistämistä sekä vuokratyösuhteessa työskentelyä. Korkeasti koulutetuilla tarkoitan henkilöitä, joilla on ammattikorkeakoulu- tai vähintään alempi korkeakoulututkinto.

Suomessa korkeasti koulutetuilla, etenkin naisilla, teetetään eurooppalaisittain verrattuna paljon työtä erilaisissa määrä- ja osa-aikaisissa työsuhteissa (Lehto ja Sutela 2008). Muissa kuin toistaiseksi voimassa olevissa kokoaikaisissa työsuhteissa työskentelee noin 25 prosenttia palkansaajista. Naisten on vaikea työllistyä pysyvästi ja työmarkkinoille näyttää muodostuneen pätkätyöläisten ryhmä noin 35-48-vuotiaista naisista, jotka valmistuivat 1990-luvun laman aikaan. Määräaikaista työtä tehdään useimmiten (yli 60 prosenttia) siksi, että pysyvää työsuhdetta ei ole tarjolla eli määräaikaisuus on vastentahtoista ja siksi erityisen rasittavaa (Kauhanen 2010).

Työn epävarmuus sinänsä ei ole uusi asia: esimerkiksi 1940- luvulta 70-luvulle miehillä teetettiin työttömyystöitä, 60- ja 70-luvuilla maalta lähdettiin Ruotsiin tai suomalaiseen kaupunkiin paremman elämän toivossa (Anttila ja Suoranta 2007, 721). Pätkätyö on kuitenkin hiljalleen yleistynyt korkeasti koulutettujen ammateissa (Lehto ja Sutela 2008), ja työtä teetetään yhä enemmän muussa kuin kokoaikaisessa toistaiseksi voimassa ole- vassa työsuhteessa. Tosin 2008 alkanut lama vähensi myös määräaikaisten ja vuokratyösuhteiden määriä etenkin yksityisellä sektorilla (Työvoimatutkimus 2009, Tilastokeskus).

Tämä artikkeli perustuu väitöstutkimukseeni, jonka taustalla ovat käsitykset työelämän murroksesta ja uudesta työstä (Vähämäki 2003, Julkunen 2008). Erilaisten työsuhteiden yleistymisen takana on moniulotteinen yhteiskunnallinen muutos, joka sallii ja vaatii, että työ on tehtävä taloudellisten tehokkuuslaskelmien perusteella (esim. Julkunen 2008). Pätkätyötä tekevät vastaavat osin työyhteisöjen eriytyneisiin työvoiman tarpeisiin (Nätti 1993,28) ja osin he sijaistavat vakinaista työvoimaa sairaus-, äitiys-, vanhempainlomien tai vuorottelu- tai virkavapaiden ajan.

Artikkeli kytkeytyy myös kerronnallisen tutkimuksen kenttään, sillä pohdin pätkätyötä tekevien ammatillista identiteettiä kerronnallisen tutkimuksen avulla. Kerronnallisen tutkimuksen pohjalla on näkemys, että teemme itsestämme ja maailmastamme ymmärrettävää kertomalla siitä tarinoita toisillemme (Gergen 1999). Kerronnallisella tiedolla voi välittää kokemuksia, jotka avaavat aikuisillekin mahdollisuuden ymmärtää ympäröivää yhteiskuntaa ja omaa elämäänsä (Löyttyniemi 2004, Hänninen 1999). Ammatti-identiteetti -käsitteellä tarkoitan elämänhistoriaan perustuvaa käsitystä itsestä ammatillisena toimijana eli millaiseksi kullakin hetkellä ymmärrämme itsemme suhteessa työ- 
hön, mihin haluamme kuulua ja millaisiksi haluamme työssämme ja ammatissamme tulla (Eteläpelto ja Vähäsantanen 2006,26).

\section{Tutkimuksen aineisto ja tutkimuskysymykset}

Keräsin tutkimukseni aineistoksi joulukuun 2005 ja tammikuun 2007 välisenä aikana 33 kerronnallista haastattelua, näistä kaksi oli ryhmähaastatteluja. Haastattelin 26 naista ja 9 miestä, kaksi on 1950luvulla syntyneitä, 1960-luvulla syntyneitä on 18 ja 1970-luvulla syntyneitä 15. Aineisto koostuu 13 tutkijan, 4 kätilön, 4 toimittajan, 4 sairaanhoitajan ja 10 projektiammattilaisen haastattelusta; osa haastatelluista kuului kahteen ammattiryhmään. (Leinikki 2009)

Tutkimus on kerronnallinen sekä aineistoltaan, analyysiltään että tiedon luonnetta koskevilta lähtökohdiltaan. Laadullinen tutkimushaastattelu tarjoaa tilaisuuden kokemusten ja selviytymiskeinojen kartoittamiseksi (mm. Siltala 2004,261). Minua kiinnostaa erityisesti se, miten haastateltavat käsittelevät pätkätyötä ja millaisia merkityksiä ne sille antavat. Käsittelen pätkätyön tuomaa taloudellista epävarmuutta, vaikutuksia työuraan, yhteiskuntaan kiinnittymistä sekä sitä, millaisia seurauksia haastateltavat kertovat pätkätyön tekemiselle elämänkokonaisuudessaan. Kysyn myös, miten työsuhteiden pätkittäisyys vaikuttaa korkeasti koulutettujen ammatilliseen identiteettiin, tarjoaako pätkitty työsuhde ammatillisen identiteetin luomiseen vaadittua pitkäkestoista kokemusta koulutusta vastaavasta työstä (Eteläpelto ja Vähäsantanen 2006) ja työyhteisön tavoista tehdä työtä (Miettinen 2007,52). Lopuksi pohdin, miten pätkätyön haitallisia vaikutuksia voisi ehkäistä.

\section{Pätkätyössä jää yhteisön reunalle}

Haastateltavani totesivat, että työpaikalla pätkätyöläisen edut voidaan asettaa vastakkain vakinaisen henkilökunnan kanssa. Tämä näkyy esimerkiksi siten, että pätkätyöläistä ei oteta mukaan työn kehittämiseen tai työpaikkakokouksiin ja hän saa väistyä tarvitsemaltaan koneelta vakituisen tieltä. Pätkätyöläinen ei pääse kalliisiin eikä ainakaan pitkäkestoisiin koulutuksiin, hän ei välttämättä pääse edes työpaikkaterveydenhuollon piiriin, pätkätyön tekijät jäävät työyhteisön reunalle. Totean, että pätkätyön synnyttämä työyhteisön reuna-asema hidastaa pätkätyön tekijän asiantunte- muksen syntymistä ja heikentää mahdollisuuksia kehittää osaamistaan.

Työsuhteen muodon synnyttämä työyhteisön reuna-asema vaikuttaa työssä jaksamiseen ammatillisen osaamisen ja identiteetin vahvistumisen kautta. Ammatillinen identiteetti syntyy pitkällä aikavälillä työtehtäviä suorittamalla ja samassa työyhteisössä toimimalla (Miettinen 2007, 52) ja siihen kuulumalla. Kuuluminen ja tunne mukana olosta merkitsevät omakohtaisesta sitoutumisesta nousevaa vaikuttamista asioiden kulkuun ja vastuun ottamista seurauksista (Poijula ja Ahonen 2007, 42). Lisäksi osallisuus parantaa työilmapiiriä, vähentää työn rasittavuutta ja vahvistaa työn kokemista mielekkääksi. (Lehto, Sutela ja Miettinen 2006). Kun työ tuntuu mielekkäältä ja työyhteisön jäsenet itsen kanssa samanarvoisilta oikeuden mukaisen kohtelun myötä, myös työssä jaksaminen paranee (Linna 2008).

Pätkätyöläisen ammatillista itsetuntoa ja työssä jaksamista heikentää myös se, että hänelle annetaan usein huonoimmat työvuorot ja loma-ajat. Siksi pätkätyön tekijä kokee vaikutusvaltansa oman elämän valintoihin kapeammaksi kuin ympärillä toimivat työtoverit, mikä ruokkii kateutta ja lisää kilpailua työpaikalla. Lisäksi kapeampi vaikutusvalta voi ohjata pätkätyön tekijän kokemusta oman toimijuuden mahdollisuuksista (Gordon 2005) koko elämänvalintojen alueella. Horisontaalisen rajaamisen ohella pätkätyö lyhentää tulevaisuuden odotetta: työuran hahmottaminen pätkän ja sen seuraavan pätkän jälkeen on hankalaa. Kuitenkin tunne siitä, että elämä ja työ kantavat, on työssä jaksamisen edellytys. Ilman tätä tunnetta työ on vaarassa supistua sattumanvaraiseksi, uuvuttavaksi pärjäilyksi.

\section{Työttömyyden vaihtoehto?}

Aiemmissa tutkimuksissa (Lehto ym. 2005, Sutela 2006) pätkätyötä on tarkasteltu lähinnä pysyvän työn vaihtoehtona. Haastattelemani pätkätyöläiset kuitenkin kokevat pätkätyön työttömyyden vaihtoehtona. Tästä kokemuskulmasta katsottuna työttömyyden ja virheen tekemisen pelko korostuvat, noin puolet pätkätyötä tekevistä kokeekin työttömyysjaksoja viiden vuoden aikana (Kauhanen 2010, seminaarikalvot). Työttömyyden pelko siirtyy myös muille elämän alueille ja sitoo monenlaiseen riskinarviointiin (Jallinoja 2006), mikä voi estää pätkätyöläistä toteuttamasta suunnitelmiaan monilla elämänalueilla. Esimerkiksi nuoret 
naiset pätkätöissä eivät välttämättä uskalla hankkia lapsia.

Muutamat haastattelemani pätkätyöläiset sanoivat roikkuvansa löysässä hirressä tulevaisuuden lupausten varassa. Heistä tuntui, että työnantajan lupauksiin jatkosta on pakko uskoa, jotta itsekunnioitus säilyy. Kun pätkä seuraa toistaan, alkaa tulevaisuuden lupaus muuttua peloksi siitä, että tämäkin loppuu. Kun usko työn jatkuvuuteen loppuu, voi myös luottamus kanssaihmisiin ja yhteiskuntaan karista. (Leinikki, 2009)

Pätkätyöläinen kohtaa asemansa epävarmuuden vuoksi haasteita, joihin hän ei ole varautunut ja joissa hänen arvonsa ja norminsa kiistetään. Suomalaisessa yhteiskunnassa törmäys voi olla erityisen suuri. Tuomo Alasoini (2006, 35) esittää, että suomalaiset luottavat muihin ihmisiin, kansaneläkejärjestelmään, koulujärjestelmään ja sosiaaliturvajärjestelmään. Haastattelemani pätkätyöläiset kuitenkin korostivat, etteivät nämä järjestelmät tarjoa heille turvaa eikä koulujärjestelmä ole valmistanut heitä pätkätyöläisen arjen kohtaamiseen. Työn psykologinen sopimus (Alasoini 2006) työssä tapahtuvasta vaihtosuhteiden tasapainosta, molemminpuolisuudesta ja vastavuoroisuudesta joutuu koulutettujen pätkätyön tekijöiden mielessä koetteille. Perinteisessä sopimuksessa työntekijä odottaa työnantajalta työsuhteen pysyvyyttä vastineeksi työpanoksestaan (mm. Poijula ja Ahonen 2007, 53), mutta pätkätyöntekijä ei saa tätä palkkiota saa. Tästä syntyy säröjä luottamukseen - ainakin yksilö- ja työpaikkatasolla.

\section{Uusi, uljas ura?}

Pätkätyössä urakehitys on monimuotoista ja monensuuntaista. Uralla voidaan tarkoittaa henkilön työkokemusten dynaamisesti kehittyvää järjestystä ajassa (Peltonen 1998), sitä voidaan pitää työkokemusten kautta saadun tiedon kertymänä (Ruohotie 2000) tai sitä voidaan tarkastella ihmisen ja organisaatioiden välisten suhteiden ja niiden kehittymisen kautta (Arthur, Hall ja Lawrence 1989). Pätkätyö vaikuttaa osaamisen kehittymiseen ristiriitaisesti: toisaalta työantaja ei välttämättä panosta pätkätyöläisen osaamiseen, toisaalta työntekijä itse näkee jatkuvassa ammattitaidon kehittymisessä työsuhdeturvan. Tutkimushaastatteluissa työurat näyttävätkin yksilöllisiltä poluilta, joilla kuljetaan omaan tahtiin parhaimmalta tuntuvia reittejä hakien.

Pätkätyössä uran yksilöllistyminen ja riippu- vuus henkilökohtaisista ominaisuuksista, olosuhteista ja sattumanvaraisesti eteen tulevista mahdollisuuksista korostuu. Tätä yksilöllistymistä voisi katsoa koulutusajattelun kritisointina: korkeakaan koulutus ei takaa vakaata työuraa eikä välttämättä edes välinettä henkilökohtaiseen riskien hallintaan (Vanttaja ja Järvinen 2006, Rinne \& Vanttaja 1999). Uran yksilöllistyminen viittaa myös työelämän monimuotoistumiseen ja uran hallinnan hankaluuteen esimerkiksi silloin, kun satunnaiset pätkätyösuhteet laajentavat osaamista ja vaikuttavat tapaan, jolla yksilöt kiinnittyvät ympäröivään yhteiskuntaan.

Yksilöllistyminen johtaa myös vertailuun saman ammattiryhmän sisällä ja ammattiryhmien välillä. Rakentavana vertailulla voi kehittää työn organisointia tai työtapoja, mutta yksilöivä vertailu voi johtaa kateuteen ja oman huonommuuden tunteen lisääntymiseen. Esimerkiksi henkilökohtaiseen työsuoritukseen perustuvien palkkausjärjestelmien on todettu lisäävän kiireen kokemusta työssä (Lehto 2006,256). Tämä puolestaan voi heikentää työyhteisön toimintaa ja työssä jaksamista.

\section{Yrittäjän referenssi vai työnhakijan taakka}

Työn ja uran ristiriitaisiin odotuksiin voi suhtautua keskittymällä työn sisältöihin ja omaan oppimiseen. Esimerkiksi määräaikaisen asiantuntijan työssä ei tekijä aina edes halua edetä uralla ylöspäin vaan hankkii laaja-alaisempaa osaamista erilaisista toimintatavoista ja toimipisteistä. Uran eteneminen kääntyy osaamisen laajenemiseksi. Työn sisältöihin ja omaan oppimiseen keskittymisen koetaan tarjoavan yksilöllisen turvan.

Joillakin aloilla pätkätyössä voi kerätä kokemusta erilaisista tavoista organisoida työ. Esimerkiksi haastattelemani eläinlääkäri kertoi, että työskenneltyään eri kunnissa ja yrityksissä hän sai koottua kokemuksia, joita pystyi soveltamaan myöhemmin suunnitellessaan vastaanottotoimintaa.

Pätkätyöhön liittyy myös kunniakas vivahde. Haastattelujen perusteella se on joskus vastahankaisuutta eli toimimista omilla ehdoilla kulttuuristen ja sosiaalisten paineiden alla, eräänlaista itsellisen toimijan aseman etsimistä mm. yrittäjäasenteen avulla. Vakinaisuuden tavoite voikin olla vain näennäinen ja työn sisältö on tärkeämpi valintakriteeri kuin työsuhteen muoto. Lisäksi pätkätyö tarjoaa joillekin tietoisen mahdollisuuden vähentää työtä ja tulojaan ja siten kulutustaan ja suoda 
enemmän vapaa-aikaa. Joskus pätkätyössä on mahdollisuus valita työjaksoja muiden elämänhallinnan projektien ehdoilla.

Kun pätkätyötä tekee monelle työnantajalle tai monissa työsuhteissa, ansioluettelo venyy. Joskus polveilevan ansioluettelon voi tulkita kuvaavan laaja-alaista kokemusta, joskus työnhakijan haluttomuutta sitoutua työnantajaan ja työhön. Yrittäjällä kokemuksen kertyminen on vakuuttava referenssiluettelo. Kyse on katsojan näkökulmien erosta, mutta eroa voi olla myös tekijän asenteessa työhön ja elämänhallinnan kokemuksessa. Yrittäjä tuntee hallitsevansa työtään, toimeentuloaan ja elämäänsä, pätkäpalkansaaja voi epäillä olevansa työnantajien armoilla. Työnhakijan asenne omaa työtään kohtaan on keskeinen hallinnan tunteen ja sen tuoman työssä jaksamisen kannalta.

\section{Sitoutumista, ylenpalttista tavoitteellisuutta ja kilpailua}

Haastattelemani pätkätyöläiset eivät mitanneet työaikoja ja joustivat ruokatunneista ja tauoista. Monet heistä menivät töihin sairaanakin ja lasten sairastaessa etsivät jonkun toinen heitä hoitamaan. Pätkätyöläisen arkeen kuuluu voimakas sitoutuminen omaan työhön.

Haastateltavat kertoivat heistä tuntuvan, että on oltava terve ja alati työhaluinen sekä mukava ja sopeutuvainen. Tämä kasvattaa pelon ja epävarmuuden tunnetta. Pelko alkaa hallita omia toimia (Furedi 2005) ja omaa elämää pyritään hallitsemaan siten, ettei työelämä häiriytyisi. Työstä tulee henkilökohtainen projekti. Elämänhallinnan yksilöllinen tavoite johtaa pätkätyön raskauttamiin sosiaalisiin valintoihin ja tekoihin, koska pätkätyön tekijät asettavat työn vaatimukset muiden vaatimusten edelle. Kun työ ohjaa elämänhallintaan liittyviä valintoja, syntyy riski siitä, että työntekijän valta tai kyky vaikuttaa oman elämän valintoihin ja yhteiskunnan muiden osapuolten päätöksentekoon kaventuu, kun hän yksilöllisin keinoin yrittää hallita yhteisöllisesti tuotettua työtilannettaan. Tarkoitan elämänhallinnalla toimintaa, joka tähtää hyvinvoinnin elämänalueittaisten tavoitetilojen saavuttamiseen, ylläpitoon ja tässä toiminnassa ilmenevien ongelmien käsittelemiseen. (Ylistö 2009)

Yksi haastateltavistani kuvasi, että pätkätyöläisenä hänen täytyy pitää oma erityisosaamisensa visusti omana tietonaan, jotta pärjää pätkätyöläisten välisessä kilpailussa ja jotta työyhteisö jatkaa hänen työsuhdettaan. Kilpailun tuoma yhteis- työn puute voikin syödä koko työyhteisön työn tuloksellisuutta ja estää tiedon kertymisen työyhteisöön. Kuitenkin yhteistyön ja tiimien merkitys työelämässä kasvaa. Esimerkiksi Casey (1995) toteaa, että työnantajat toivovat työntekijän sitoutuvan työtiimiin ammattinimikettä enemmän.

\section{Sosiaalinen pääoma ja pätkätyö}

Sosiaalinen pääoma on moniulotteinen ja määrittelijästä riippuvainen käsite. Tässä tarkoitan sosiaalisella pääomalla sosiaalisen rakenteen aineettomia ominaisuuksia, jotka liittyvät ihmisten välisiin verkostoihin, normeihin ja luottamukseen, mitkä edistävät vuorovaikutusta, tavoitteita ja toimintaa (Putnam 2000). Robert D. Putnam (2000) määrittää, että sosiaalinen pääoma merkitsee yhteisön toimivuutta ja kiinteyttä ja sen osia ovat moraaliset velvollisuudet, luottamus sekä sosiaaliset verkostot (eli mm. työyhteisöt ja vapaaehtoiset yhdistykset). Sosiaalinen pääoma on sekä yksilön että yhteisön omaisuutta ja sen määrään ja sisältöön vaikuttavat ratkaisevasti yksilöiden identiteetit. Vastavuoroisesti yksilöiden identiteetteihin vaikuttaa sosiaalinen pääoma.

Sosiaalinen pääoma kasautuu verkoston ja sen normien sekä yhteisen identiteetin ja tietoisuuden rakentamisen tuloksena. Sosiaalista pääomaa voidaan tuottaa luomalla olosuhteita ja edellytyksiä uuden tiedon ja oppimien mahdollistamiseksi työn, koulutuksen ja arjen yhteisöjen verkostoissa kuten työyhteisöissä (Oksanen ja muut 2008,8). Jos yhteisössä tuotetaan sosiaalista pääomaa yhteisen identiteetin rakentamisen avulla ja tämä rakentaminen tapahtuu osin tarinoiden (mm. Löyttyniemi 2004) avulla, niin osa työyhteisön sosiaalista pääomaa on sosiaalinen tarinavaranto eli se kulttuuristen kertomusten joukko, joka yksilölle työssä tarjoutuu. Tarinoita syntyy ja niitä kerrotaan, kun ihmiset kohtaavat sosiaalisessa vuorovaikutuksessa, myös työyhteisöissä. Haastattelujen perusteella näyttää siltä, että pätkätyösuhde voi jättää tekijänsä tämän työyhteisön tarinavarannon ulkopuolelle ja heikentää vaihtoehtoisen toiminnan näkymää.

Sosiaaliseen pääomaan sisältyvät yhteistyökyky, luottamus ja luovuus (Putnam 2000). Suomalaisessa työelämässä työtä säätelevät monet instituutiot (mm. ammattiyhdistykset) ja lait. Suomea on jopa sanottu luottamusyhteiskunnaksi (Alasoini 2006). Yksilön kannalta lakia noudattava ja yhdessä neuvoteltu työsopimus luo varmuutta ja 
ennustettavuutta elämään eli lisää luottamusta. Sosiologiassa luottamuksella viitataan tilanteisiin ja suhteisiin, joissa on petetyksi tulemisen mahdollisuus (Julkunen 2007,45). Julkunen (2007) toteaa tätä luottamusta olevan eniten ihmisillä, joiden elämänkulku on ollut onnekas ja joilla on paljon toimintaresursseja. Suomessakin tämä luottamus saattaa kuitenkin olla koetuksella, koska petetyksi tulemisen mahdollisuuden arvioidaan suurentuneen globalisaation myötä (Siltala 2004). Luottamuksen rapisemista kuvaavat myös sosiaalisen tuen väheneminen työpaikoilla (Lehto ja Sutela 2003) sekä työolobarometrin huomiot työnteon koetun mielekkyyden (Alasoini 2006,53 - 54) laskusta. Pätkätyösuhde heikentää työntekijän luottamusta työnantajaan, koska sen lähtökohtana on työnantajan rajallinen halu sitoutua työntekijään.

Ammatillisen identiteetin vahvistuminen ja luottamus tulevaisuuteen syntyvät ajan kanssa, kun työsopimukset pitävät sekä työnantajan että työntekijän puolelta ja koulutettu työntekijä pääsee osaksi ammattikuntaa, verkostoja ja työryhmiä. Tuttuuteen perustuva luottamus muuttuu rakenteelliseksi luottamusverkostoksi, joka ilmentää sosiaalista pääomaa. (Ilmonen 2002). Tämä sosiaalisen pääoman kasvu tukee yksilön toimijuuden tunteen syntymistä. Kun pätkätyössä luottamusverkosto on rajallinen ja joskus satunnainen, voi syntyä monisuuntainen prosessi, joka toisaalla vahvistaa yksilön ja yhteisöjen sosiaalista pääomaa ja toisaalla heikentää sitä. Sosiaalinen pääoma voi kasvaa, kun työpaikat vaihtuvat ja verkostot ja yksilölle tarjoutuvat tarinamallit ja mallitarinat (Löyttyniemi 2004) laajenevat horisontaaliurien myötä, mutta se voi myös heiketä, kun luottamus verkostoa, vastavuoroisuutta ja yhteisten asioiden hoitumista kohtaan vähenee. Luottamus karisee etenkin, jos pätkätyöstä ei ripeästi pääse pysyvän työn pariin, jos pätkätyö nähdään vain pysyvän työn puutteena tai jos pätkätyöntekijät saavat osakseen epätasa-arvoista kohtelua.

Tutkimukseni perusteella näyttää myös siltä, että työpaikan sosiaalinen vuorovaikutus muokkaa sosiaalisen pääoman kertymistä. Etenkin esimiehiltä saatu tuki, tehtäväsuuntautunut asenne ja organisaatio palkkapolitiikan avoimuus ja reiluus vaikuttavat pätkätyöntekijän kokemuksiin. Jos useimmat organisaation jäsenet ovat pätkätöissä ja pätkätyön syyt ovat työyhteisön jäsenten tiedossa, pätkätyö ei tunnu samalla tavalla epäoikeudenmukaiselta kuin silloin, kun osa työyhteisön jäsenistä on pysyvässä työsuhteessa. Pätkä- työntekijän epäoikeudenmukainen kohtelu puolestaan heikentää myös ympäröivän työyhteisön sosiaalista pääomaa.

\section{Pätkätyö ja työmoraali}

Perinteisesti moraali on jaoteltu kognitioon, tunteisiin ja toimintaan. Rest ym. (1999) alkoivat kuvata moraalin moniulotteisuutta jakamalla moraalisen toiminnan neljään osatekijään. Restin mallissa moraali koostuu moraalisesta sensitiivisyydestä, moraalisesta ajattelusta ja päätöksenteosta, valmiudesta toimia moraalisen motivoinnin pohjalta sekä moraalisesta selkärangasta. Sensitiivisyydellä Rest tarkoittaa tilanteen ja osapuolten määrittelyä ja tulkintaa eri osapuolien oikeuksien ja hyvinvoinnin näkökulmasta ja vaihtoehtoisten skenaarioiden huomaamista. Moraalinen ajattelu ja päätöksenteko puolestaan liittyvät oikeudenmukaisimman toimintavaihtoehdon valintaan ja moraalinen selkäranka kuvaa kykyä ja rohkeutta toimia moraalisten periaatteiden mukaan. Mallissa tunne ja kognitio ovat yhteen kietoutuneita.

Restin mallia on käytetty asiantuntija-ammateissa työskentelevien moraalin tutkimiseen. Tutkimuksissa (mm. Myyry 1997) on selvinnyt, että kyky tulkita moraalisia ongelma kehittyy ammattieettisen opetuksen myötä. Työssä, myös pätkätyössä, luodataan sekä omaa että työyhteisön moraalia. Työyhteisön toimintamoraalia luodaan yhdessä ja moraalin luotaaminen ulottuu myös henkilökohtaisen alueelle.

Eettiset kysymykset ovat mukana myös töiden yhteiskunnallisessa järjestämisessä. Ammatit edustavat niille yhteiskunnallisesti legitimoitua valtaa, mihin liittyy myös vastuu. Ammatillista identiteettiä luodaan persoonallisen ja sosiaalisen vuoropuheluna (Eteläpelto ja Vähäsantanen 2006,43-44) ja ammatillista moraalia luodataan pohtimalla omaa sitoutumista. Jos pätkätyön tekijä on vain osittain sitoutunut työyhteisöön ja vain osittain osallinen työyhteisön moraali luomisesta, se vaikuttaa hänen sitoutumiseensa moraalin noudattamiseen. Esimerkiksi hoitotyössä pätkätyöntekijöiden sitoutumisen rapistuminen saattaa tuoda hoidollisia riskejä ja jopa vaarantaa potilasturvallisuuden.

Toisaalta työmoraalin pohtiminen pätkätyössä ei välttämättä ulotu työyhteisön sitoutuneena osana toimimisen tasolle, koska pätkätyö ohjaa sitoutumaan itse työtehtäviin ja niissä toteutettavaan moraaliin. Henkilökohtainen korkea työmoraali voi tarkoittaa asiakkaan hyvää palvelua, mutta työn- 
antajan ja työtoverin toiveiden ohittamista. Toisaalta, pätkätyö myös antaa tilaisuuksia tarkastella useiden työyhteisöjen toiminnan moraalia ja neuvotella omasta ammatillisesta moraalistaan vaihtuvissa ympäristöissä ja jopa kohentaa työtehtäviin suuntautuvaa työmoraalia.

\section{Johtopäätökset ja työn teettämisen tavan muutokseen vastaaminen}

Pätkätyöllä on vaikutuksia sitä tekevien työuraan ja taloudelliseen toimeentuloon. Samalla, kun pätkätyö sitoo tekijäänsä entistä enemmän työhön, se tarjoaa vain osittaista osallisuutta työn yhteisöihin ja sulkee vaihtoehtoisia valintoja.

Pätkätyö vaikuttaa sekä yksilön että työyhteisöjen toimintatapoihin. Pätkätyöntekijät esimerkiksi päivittävät ansiokansiotaan jatkuvasti uutta työsuhdetta hakiessaan ja työyhteisöt perehdyttävät toistuvasti uusia työntekijöitä. Pätkätyö heijastuu siten koko työyhteisöön ja heikentää työelämän laatua ja jopa työmoraalia, se vaikuttaa työyhteisöjen ja koko yhteiskunnan sosiaaliseen pääomaan ja luottamukseen. Siksi pätkätyö ei ole vain yksilön ongelma ja ominaisuus, eikä pätkätyöläisen pitäisi joutua kamppailemaan yksin pätkätyössä pärjätäkseen. Tarvitaan laajoja yhteiskunnallisia toimia. Erityisesti tarvitaan keinoja, joilla erilaiset sosiaaliturvan osat voidaan sovittaa vaihtelevaan tai vähäiseen työmäärään siten, että järjestelmät eivät nöyryytä yksilöä, että yksilöt voivat kieltäytyä kohtuuttomilla ehdoilla tarjotusta työstä ja että työnteko ei heikennä toimeentuloa. Toisaalta tarvitaan myös arjen työkaluja määräaikaista työtä tekeville ja sitä johtaville sekä työyhteisöille, joissa työskentelee määräaikaisia työntekijöitä.

Määräaikaisten työsuhteiden yleistymien yhdistyy paikallisen sopimisen lisääntymiseen. Tämä asettaa vaatimuksia paitsi työyhteisöille ja yksilöille, myös ammattiliitoille. Monet haastateltavani toivoivat, että liitot keskittyisivät tasapuolisesti sekä toistaiseksi voimassaolevalla sopimuksella että pätkätyösuhteessa työtä tekevien edunvalvontaan ja edunvalvonta edellytysten luomiseen. Ammattiliittojen pitäisi huolehtia myös pätkätyöläisten työehdoista, työn mitoituksista, mahdollisuuksista lomaan ja koulutukseen sekä lisäksi toimivasta ja joustavasta sosiaaliturvajärjestelmästä. Edunvalvonnan edellytyksistä keskeisin eli luottamus kiertyy pätkätyöhön siten, että työntekijällä täytyy olla luottamusta sekä taustaryhmäänsä, itseensä että tulevaisuutensa mahdollisuuksiin ja lisäksi uskallusta huolehtia eduistaan. Jos uskallus pätkätyön vuoksi karisee, luottamus heikkenee ja edunvalvonta vaikeutuu.

\section{Lähteet}

Alasoini, T. (2006). Työnteon mielekkyyden muutos Suomessa vuosina 1992-2005. Työolobarometrin aineistoihin perustuva analyysi. Työministeriö.

Anttila, A-H ja Suoranta, A. (2007). Pärjäämisen ajat - horjuvat työt. Helsinki: Työväen historian ja perinteen tutkimuksen seura.

Arthur, M., Hall D. \& Lawrence, B (1989). Generating new directions in career theory. the case for transdisciplinary approach. Teoksessa Arthur, M., Hall, D. \& Lawrence B. (ed.). Handbook of career theory. New York, Cambridge University Press 7-25

Casey, C.(1995). Work, Self and society after industrialism. Routledge, London and New York.

Eteläpelto, A., Vähäsantanen K. (2006). Ammatillinen identiteetti persoonallisena ja sosiaalisena konstruktiona, teoksessa Eteläpelto, A., Onnismaa, J.(2006). Ammatillisuus ja ammatillinen kasvu. Aikuiskasvatuksen 46.vuosikirja. Kansanvalistusseura ja Aikuiskasvatuksen Tutkimusseura.

Eteläpelto, A., Onnismaa, J. (2006). Ammatillisuus ja ammatillinen kasvu. Aikuiskasvatuksen 46.vuosikirja. Kansanvalistusseura ja Aikuiskasvatuksen Tutkimusseura.

Eteläpelto, A., Collin, K. ja Saarinen J. (toim.) (2007). Työ, identiteetti ja oppiminen. WSOY Oppimateriaalit.

Furedi, F. (2005). Culture offear. Risk-taking and the morality of low expectation. Revised edition. Continuum, Forfolk.

Gordon, T. (2005). Toimijuuden käsitteen dilemmoja. Teoksessa Meurman-Solin, Anneli ja Pyysalo, Ilkka (toim.). Ihmistieteet tänään. Helsingin tutkijakollegiumin julkaisuja, Helsinki: Gaudeamus.

Houtsonen, J., Kauppila, J. ja Komonen, K. (2000). Koulutus, elämänkulku ja identiteetti. Kasvatussosiologisia avauksia suomalaiseen oppimiseen. Sosiologian laitoksen julkaisuja nro 3. Joensuun yliopisto. 
Hyvärinen,M . (2006). Kerronnallinen tutkimus. Julkaistu internetissä 2006 http:// www.hyvarinen.info/page02-kerrot.htm

Hänninen, W. (2002). Sisäinen tarina, elämä ja muutos (elektroninen aineisto), Tampereen Yliopisto, Tampere https.// www.opiskelijakirjasto.lib.helsinki.fi/ekirjat/ index.jsp?isbn=951-44-5597-5

Jokivuori P., Latva-Karjanmaa R., Ropo A. (toim.) (2006). Työelämän taitekohtia. Työministeriö.

Julkunen, R., Nätti, J. ja Anttila, T.(2004). Aikanyrjähdyksiä. keskiluokka tietotyön puristuksessa. Tampere: Vastapaino.

Julkunen, R. (2007). Työ, talouden ja minän välissä. Teoksessa Eteläpelto, A., Collin, K. ja Saarinen J. (toim.). Työ, identiteetti ja oppiminen. Helsinki: WSOY Oppimateriaalit.

Julkunen, R. (2008). Uuden työn paradoksit. Keskusteluja 2000-luvun työprosess(e)ista. Tampere: Vastapaino.

Kauhanen, M. (2010). Pätkätyöseminaari Vihreän eduskuntaryhmän kokoushuoneessa 4.5.2010.

Kinnunen M-L. (2005). Allostatic load in relation psychosocial stressors and health. Jyväskylä Studies in Education, Psychology and Social Research, 275, Jyväskylän yliopisto.

Koivumäki, J., Kankaanpää, A. Melin, H. ja Blom, R.(2006). Luottamus työorganisaatioissa. empiirinen tarkastelu. Artikkeli teoksessa Jokivuori P., Latva-Karjanmaa R., Ropo A. (toim.) (2006). Työelämän taitekohtia. Työministeriö.

Lehto, A-M. (2006). Työpaineet ja kiirekokemukset. Artikkeli teoksessa Lehto, A-M., Sutela, H, ja Miettinen, A. (toimi.) (2006). Kaikilla mausteilla. Artikkeleita työolotutkimuksesta. Tilastokeskus.

Lehto, A-M., Lyly-Yrjänäinen, M.ja ja Sutela H. (2005). Pysyvän työn toivossa. Määräaikaisten työsuhteiden käytöstä ja kokemisesta. Työpoliittinen tutkimus. Työministeriö.

Lehto, A-M., Sutela, H. (2006). Uhkia ja mahdollisuuksia. Työolotutkimuksen tuloksia 1977-2003. Tilastokeskus, Helsinki.

Lehto, A-M., Sutela, H. ja Miettinen, A.(toimi.) (2006). Kaikilla mausteilla. Artikkeleita työolotutkimuksesta. Tilastokeskus.

Lehto, A-M.ja Sutela, H.(2008). Työolojen kolme vuosikymmentä. Työolotutkimusten tuloksia
1977-2008, Tilastokeskus.

Leinikki, S. (2009). Pelon ja toivon väliss äpätkätyöläisen urakerronta. Työelämäjulkaisut. TJS Opintokeskus. Sähköisesti: https://www.doria.fi/bitstream/handle/10024/ 44844/pelonjat.pdf? sequence $=1$

Linna, A (2008). ”SE ON NIIN VÄÄRIN! ” Kokemus johtamisen oikeudenmukaisuudesta ja sen muuttaminen kuntaorganisaatiossa. Akateeminen väitöskirja. Turku: Turun kauppakorkeakoulu.

Lähteenmäki, L. (2004). Onks tää nyt ihan reiluu? Pätkätyötä tekevien äitien kokemukset työn ja perheen yhteensovittamisesta. Sosiologista keskustelua B 43. Turun Yliopisto.

Löyttyniemi, V. (2004). Auscultatio Medicini: Kerrottu identiteetti, neuvoteltu sukupuoli. Jyväskylä: Minerva.

Miettinen, A. (2007). Pätkätyön tulevaisuus? Asiantuntijanäkemyksiä määräaikaisen työn kehittämistarpeista ja tulevasta kehityksestä Suomessa. Katsauksia E 27/2007, Helsinki: Väestöntutkimuslaitos.

Myyry, L. (1997). Ammattietiikka. Opettaako koti, korkeakoulu vai Siperia? Helsingin yliopisto.

Ojala, J., Hakoluoto, T., Hjort, A. ja Luoma-aho, V.(2006). Hyvä paha sosiaalinen pääoma. Artikkeli teoksessa Jokivuori P., Latva-Karjanmaa R., Ropo A. (toim.) (2006). Työelämän taitekohtia. Työministeriö.

Oksanen, T.,Vahtera, J., Kouvonen, A., Virtanen, M., Linna, A., Elovainio, M., Pentti, J. ja Kivimäki, M. (2008). Sosiaalinen pääoma työelämän muutoksissa. Vaikutukset mielenterveyteen ja depression ilmaantuvuuteen? Helsinki: Työterveyslaitos.

Palanko-Laaka, K.(2005). Määräaikaisen työn yleisyys, käytön lainmukaisuus ja lainsä̈̈dännön kehittämistarpeet. Työministeriö.

Poijula, S. ja Ahonen, R. (2007). Irtisanotut. Menetys, muutos ja selviytyminen. Helsinki: Kirjapaja.

Rest, J. Narvaez D., Bebeau M. Stephen T.(et al) (1999). Postconventional moral thinking: a Neo-Kohlbergian approach. Mahwah, NJ: L. Erlbaum Associates.

Ruohotie, P. (2000). Oppiminen ja ammatillinen 
kasvu. Helsinki: WSOY.

Sutela H., Lehto A-M. ja, Lyly-Yrjänäinen M. (2005). Pysyvän työn toivossa. määräaikaisten työsuhteiden käytöstä ja kokemisesta. Työministeriö.

Sutela, H. (2006). Työsuhteen määräaikaisuuden kokeminen. Teoksessa Lehto, A-M., Sutela, H. ja Miettinen, A. (toim.) (2006): Kaikilla mausteilla. Artikkeleita työolotutkimuksesta. Tilastokeskus.

Vanttaja, M. ja Järvinen, T. (2006). Oppiminen ja identiteetti muuttuvassa yhteiskunnassa.

Teoksessa. Mäkinen Jarkko, Olkinuora Erkki, Rinne Risto ja Suikkanen Asko (toim.): Elinkautisesta työstä elinikäiseen oppimiseen.
Jyväskylä: PS-kustannus.

Virtanen, M., Kivimäki, M., Joensuu, M., Virtanen, P. Elovainio, M., Vahtera, J. (2005). Temporary employment and health. a review. International Journal of Epidemiology 2005;34, 610-622

Vähämäki, J. (2003). Kuhnurien kerho. Vanhan työn paheista uuden työn hyveiksi. Helsinki: Tutkijaliitto.

Ylistö, S. (2009). Tavoiteteoreettinen elämänhallinta, selvyyttä sekavaan käsitteistöön. Sosiologia 9/2009, 286-299.

Artikkeli saapui toimitukseen 7.4.2010.

Se hyväksyttiin julkaistavaksi toimituskunnan kokouksessa 15.8.2010.
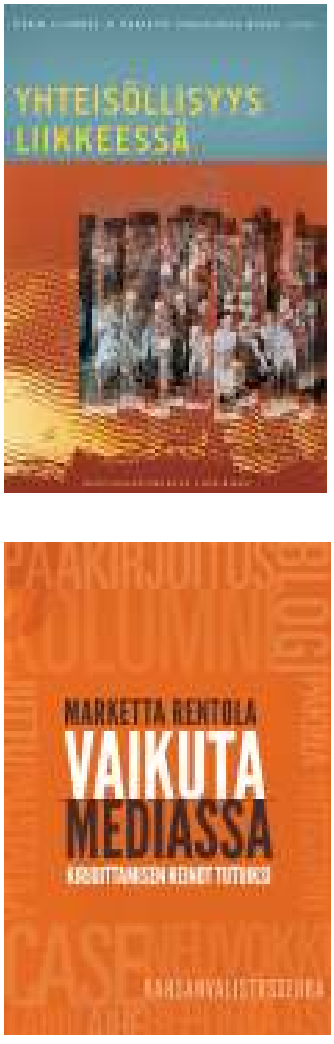

\section{Aikuiskasvatuksen 48. vuosikirja}

Karin Filander \& Marjatta Vanhalakka-Ruoho (toim.)

\section{Yhteisöllisyys liikkeessä}

Teos haarukoi yhteisöllisyyttä parin kymmenen kirjoittajan voimin tieteenalojen kuppikuntien rajat ylittävällä otteella.

Kansanvalistusseura ja Aikuiskasvatuksen Tutkimusseura 2009, 391 sivua, OVH 32 euroa.

Aikuiskasvatuksen 49. vuosikirja tulossa keväällä: Anneli Eteläpelto, Tuula Heiskanen \& Kaija Collin (toim.) Valta, toimijuus ja aikuiskasvatus

\section{Marketta Rentola}

\section{Vaikuta mediassa - kirjoittamisen keinot tutuiksi}

Vaikuta mediassa -kirja esittelee lukijalle mediakirjoittamisen toimintaperiaatteita ja juttutyyppejä. Viestintäkouluttaja Marketta Rentola kertoo, millaisia kirjoittamisen keinoja lehdet suosittelevat ja mistä se johtuu. Käytännönläheinen kirja antaa välineitä tekstien purkamiseen.

Kansanvalistustusseura 2010, 196 sivua, OVH 32 euroa.

\section{Tulossa myös}

Birgitta Romappanen \& Anita Kallavuo (2011). Johtajuuden rakentuminen.

Eväitä lähijohtamiseen.

Risto Rinne \& Arto Jauhiainen (toim.). Aikuiskasvatus ja demokratian haaste 